\title{
How Does the Accounting Treatment of the Environment Transaction and How it Impacts to Company's Performance? Case from Indonesia
}

\section{Einde Evana' | Lindrianasari Lindrianasari2* (1) | R. Weddie Andriyanto3}

${ }^{1}$ Universitas Lampung, Department of Accounting, Bandar Lampung, Indonesia

${ }^{2}$ Universitas Lampung, Department of Accounting, Bandar Lampung, Indonesia

3Universitas Lampung, Department of Accounting, Bandar Lampung, Indonesia

*Correspondence to: Lindrianasari Lindrianasari, Universitas Lampung, Faculty of Economics and Business, Department of Accounting, Jl. Prof. Dr. Sumantri Brojonegoro No. 1, Bandar Lampung 35145, Indonesia.

E-mail: lindrianasari@feb.unila.ac.id

\begin{abstract}
This study aims to investigate the awareness of big companies in Indonesia on the allocation of environmental costs. This research is very important to do, given that the company's operational effects as contributing very large carbon emissions (especially companies whose activities are in contact with nature). The method used in this research is observation, by tracing the existence of environmental cost in every big company in Indonesia, which is in database Bloomberg. The number of samples of this study is 2,043, for all companies in the period of observation 2004-2017. The results of this study indicate a relatively slow response of companies in responding to regulations issued by the state. This also indicates the low compliance of large companies in Indonesia for the implementation of the rules, in terms of accounting known as the recognition and measurement of accounting for environmental transactions.
\end{abstract}

Keywords: environmental cost, measurement, recognition, recording, reporting.

Article info: Received 6 October 2018 | revised 19 December 2018 | accepted 28 January 2019

Recommended citation: Evana, E., Lindrianasari, L., \& Andriyanto, R. W. (2019). How Does the Accounting Treatment of the Environment Transaction and How it Impacts to Company's Performance? Case from Indonesia. Indonesian Journal of Sustainability Accounting and Management, 3(1), 49-54. https://doi.org/10.28992/ijsam.v3i1.71.

\section{INTRODUCTION}

The negative impact of environmental degradation has awakened the global community on the importance of environmental and social management. The awareness of various parties on environmental issues for human well-being in the future is demonstrated by the activities of the world organization. The Conference on Environment and Development held at the Earth Summit on 3-14 June 1992 in Rio de Janeiro, Brazil, attended by 35,000 participants consisting of heads of state, researchers, NGOs, journalists, academics and other concerned parties as a representative of 172 countries, became an important momentum for the issue of save the world. The main issues discussed in 1992 were environmental issues, including global warming, the 
destruction of forests and endangered species, and ideas on the development of environmentally friendly industries. The Earth KKT in Rio de Janeiro was noted as one of the most important discussions on the environment at the world level.

An important environmental discussion continues on a global level has recorded some valuable activities such as, Conferences of the Parties-COP (annual conference started in 1995 to assess progress on climate change); Kyoto Protocol (1997 concludes and establishes legally binding obligations for developed countries to reduce their greenhouse gas emissions in the period 2008-2012); Cancún Agreement (2010, states that global warming in the future should be limited depending on the type of industry); Paris Agreement (2015 in COP 12, which regulates emission reductions through joint commitments of the world's nations-including Indonesia, which came into force on 4 November 2016).

Up to July 2018, UNFCCC members have signed agreements in the Paris Agreement as many as 195, and 179 of which have become part of that commitment. Meanwhile, the long-term goal of the Paris Agreement is to keep the global average temperature rise to well below $2^{\circ} \mathrm{C}$ above the industry level, as its impact will substantially reduce the risks and impacts of climate change. Paris Agreement is an important agreement related to the United Nations Framework Convention on Climate Change (UNFCCC), which deals with the mitigation, adaptation, and financing of greenhouse gases, which will begin in 2020 (Seo, 2017).

In relation to the financing of greenhouse gases and the environment in general, responsibility is not limited to one party, but all parties must take responsibility. However, especially for industries that have a large impact on the environment, environmental financing should be sought in corporate planning. Indonesia as one of the archipelagic countries with the longest coastline in the world is very vulnerable to the effects of climate change, one of which is on sea level rise. For that, Indonesia must play an active role in reducing the impact of climate change. One of Indonesia's active role in environmental issues is seen from the enactment of Law No. 17 of 2004 on Ratification of the Kyoto Protocol to the United Nations Framework Convention on Climate Change.

Public policy is whatever the government will choose to do or not to do. Public policy theory can be used in research areas related to government policy. In Big Indonesian Dictionary, regulation implies controlling human or community behavior with rules or restrictions. Meanwhile, Scott (2015) explains that there are two sides in looking at the theory of regulation, namely public interest theory and interest group theory. Public interest theory explains that regulation must be able to maximize social welfare. Meanwhile, interest group theory explains that regulation is the result of lobbying of some individuals or groups that defend and convey their interests to the government. Public interest theory is made primarily to provide protection and kindness to the general public. Sometimes, policies are made with the aim of maximizing the welfare of certain groups and for special interests. Policies related to the environment, are expected to serve the interests of the public, not groups or interests.

In the early period of widespread social and environmental issues discussed in various research in the field of diverse science, it is mentioned that social disclosure can be seen as a way to respond the change of public perception related to corporation activity. Grand theory used in this study is Suchman (1995); Arvidsson (2010); Kamal \& Deegan (2013), Lindrianasari et al. (2018). This theory explains that the practice of preserving/maintaining legitimacy and/or fulfilling community expectation, furthermore, the CSR practice is aimed at avoiding the negative effects of corporate receives criticism from media. Furthermore, legitimacy theory also explains that corporate must fulfill values in the environment where the company operates. Legitimacy emphasis on the value system in the community and it predicts that a company will be able to survive if the company is in line with the value system in the certain community (Lindrianasari et al., 2018). 
In line with the explanations and predictions of several theories above (legitimacy theory and public policy theory), this study suggests that the company's response to key environmental issues and government policies (including ratifying the Kyoto Protocol through Law No. 17 of 2004) is positive. In other words, that the company will allocate funds to overcome the negative impact of the company's activities on the environment and society. Thus, it will look the number of environmental costs that exist in the company's financial statements. Furthermore, the company will conduct and report recognition, measurement, recording, reporting, an environmental cost for transactions related to the environment.

This study aims to investigate the awareness of big companies in Indonesia in the allocation of environmental costs. This research is very important to do, considering the company's operational effects in contributing very large carbon emissions, especially companies whose activities are exploiting and related to natural resources. In accordance with Law No. 40 of 2007 on Limited Liability Companies, as well as Government Regulation No. 47/2012 on Social and Environmental Responsibility, companies whose activities exploit and relate to natural resources shall allocate social and environmental costs. For this reason, this study was conducted. The objective is, to assess the compliance of large companies in Indonesia in the implementation of the rules, in terms of accounting are recognition, measurement, recording, and accounting reporting on environmental transactions. The results of this study indicate the response of sample companies that are relatively slow in responding to regulations issued by the state.

\section{METHODS}

This study uses financial report data obtained from Bloomberg database. The data used was obtained from the Bloomberg database because up to now, Bloomberg has become one of the largest financial data providers in the world. So, that this research can be realized in the data provided by this provider. Some previous studies that also use Bloomberg databases are (Sharfman \& Fernando, 2008; Zunino et al., 2008).

Table 1 Sample

\begin{tabular}{lccccc}
\hline No. & Years & Data Collected & Envi_Cost & Envi_Disclosure & CSR_Disclosure \\
\hline 1. & 2004 & 100 & $0.00 \%$ & $0.00 \%$ & $0.00 \%$ \\
2. & 2005 & 104 & $0.00 \%$ & $0.00 \%$ & $0.00 \%$ \\
3. & 2006 & 109 & $0.00 \%$ & $0.00 \%$ & $0.92 \%$ \\
4. & 2007 & 122 & $0.00 \%$ & $2.46 \%$ & $3.28 \%$ \\
5. & 2008 & 127 & $0.79 \%$ & $3.94 \%$ & $5.51 \%$ \\
6. & 2009 & 130 & $1.54 \%$ & $7.69 \%$ & $10.77 \%$ \\
7. & 2010 & 144 & $2.08 \%$ & $10.42 \%$ & $13.89 \%$ \\
8. & 2011 & 149 & $2.68 \%$ & $11.41 \%$ & $15.44 \%$ \\
9. & 2012 & 150 & $3.33 \%$ & $12.00 \%$ & $16.00 \%$ \\
10. & 2013 & 153 & $2.61 \%$ & $14.38 \%$ & $16.99 \%$ \\
11. & 2014 & 153 & $3.92 \%$ & $13.73 \%$ & $16.99 \%$ \\
12. & 2015 & 149 & $4.03 \%$ & $10.74 \%$ & $12.08 \%$ \\
13. & 2016 & 211 & $8.87 \%$ & $24.12 \%$ & $54.12 \%$ \\
14. & 2017 & 242 & $11.52 \%$ & $44.67 \%$ & $74.78 \%$ \\
\hline \multicolumn{7}{c}{ Data Total } & 2,043 & 0.02955706 & 0.111105161 & 0.171978398 \\
\hline
\end{tabular}

Source: Bloomberg database

The sample is all available data of company financial report in Indonesia period 2004-2017 (14 years). Secondary data used in this study were obtained by using the code envi_cost, envi_disclosure, csr_disclosure. 
Then the data is collected and the sample is selected (cleaned). Only companies that have complete data are selected to be the final sample of the study. The total sample end (data) used in this study is 2,043 years of the firm (see Table 1). This long-term observation is done to see the response of big companies listed on the Indonesian Stock Exchange on the policy issued by the state.

\section{RESULTS AND DISCUSSION}

Table 1 shows the average, since Indonesia ratified the Kyoto Protocol, there are only $2.95 \%$ of companies that record and report environmental costs in the company's financial statements. In 2017, companies that record and report environmental costs are approximately $11.52 \%$. Meanwhile, the level of disclosure of environmental information and CSR looks better than the environmental cost reporting.

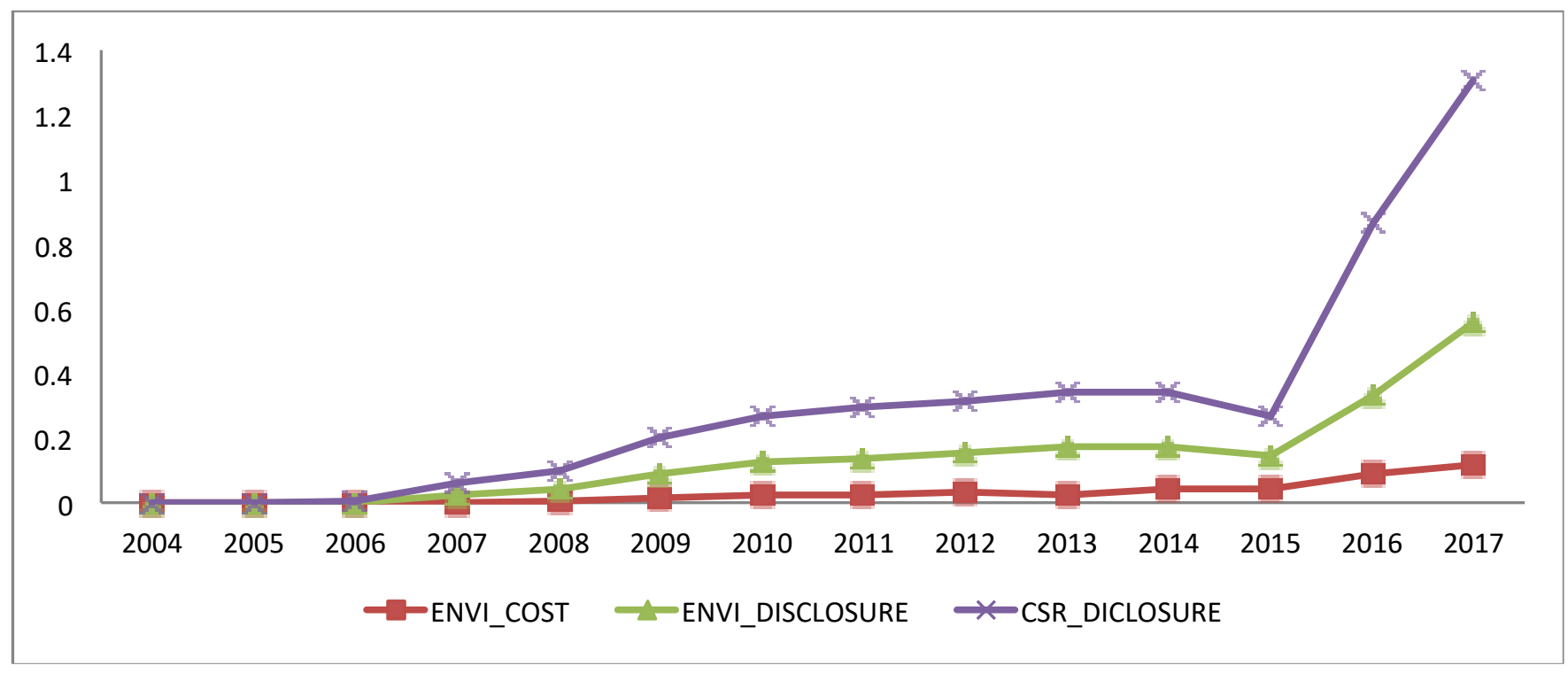

Figure 1 Trend of Environmental Cost, Environmental Disclosure and CSR Disclosure

The findings of long-term observations on large companies in Indonesia for the period 2004-2017 show the low allocation of environmental funds provided by large companies in Indonesia. Of the three components of the observed variables, environmental costs received the lowest portion. Research that has been only discussed the issue of information disclosure of environmental activities and information disclosure of CSR activities conducted by the company, was not in line with the allocation of funds for the environment itself. These results provide the same explanation with the findings of Asmaranti \& Lindrianasari (2014). Figure 1 illustrates the performance of environmental costs, environmental disclosures, and CSR disclosures throughout the study period of this study. Environmental costs are very low among other variables. In 2017, the average allocation of environmental costs recorded in large companies in Indonesia was only $11.52 \%$. Meanwhile, environmental disclosure and CSR disclosure were $44.67 \%$ and $74.78 \%$ respectively.

Furthermore, Table 2 shows the correlation test results among variables. Testing conducted on a sample of 2,043 years of the company shows that environmental costs are positively associated with the company's net income. These results indicate that companies that have a record of environmental costs tend to have higher profits compared to companies that do not. Likewise, the company's operating income, higher revenues 
are found in companies with records of environmental cost allocations. Revenue and net income, both found to be significantly positively related to environmental costs.

Table 2 Correlation Test Result

\begin{tabular}{ccccc}
\hline & & Revenue & Total Asset & Net_Income \\
\hline Envi_Cost & Pearson Correlation & $0.05^{*}$ & -0.014 & $0.069^{* *}$ \\
& Sig. (1-tailed) & 0.046 & 0.292 & 0.003 \\
& $\mathrm{~N}$ & 2,043 & 2,043 & 2,043 \\
\hline
\end{tabular}

** Correlation is significant at the 0.01 level (1-tailed).

* Correlation is significant at the 0.05 level (1-tailed).

Meanwhile, total assets were found to be negative relationship related to environmental costs. These results confirm many previous studies, especially research in Indonesia, which found that larger firms have lower social and environmental activity than low-asset firms, relatively. However, the relationship between total assets and environmental costs is not significant. This result is in line with previous research by (Lindrianasari et al., 2018).

\section{CONCLUSION}

This finding is quite reasonable to conclude that legitimacy theory capable of explaining the relationship between the recognition, measurement, recording, and reporting on environmental transactions in companies associated with the company's external stakeholders award. The impact of acknowledgment activities, measurements on environmental transactions that ultimately result in the recording and reporting of environmental costs, have made the company's products more desirable, companies concerned about the environment will certainly gain legitimacy from society. This legitimacy is one of the factors of corporate sustainability.

However, the low level of companies that have environmental transactions and reporting shows that there is still a low level of corporate desire to support the government's ratification of reducing carbon emissions (Kyoto Protocol objectives) through Law no. 17 of 2004. The findings of this study are expected to provide useful information to the company that there is no futility in conducting environmental transactions as support for the government work program. Because, in addition to the company shows its compliance with existing regulations, the company will also benefit in increasing the amount of revenue and net income of the company.

This research also attempts to convey a message to the regulator to hasten codification of accounts that can be used by companies to record environmental transactions. The existence of this codification was ultimately used as a reference for companies in recording and reporting more appropriate environmental accounting reporting. The board of financial accounting standards in Indonesia must also immediately issue environmental accounting standards that contain all aspects of accounting methods for environmental transactions, from recognition, measurement, recording, to reporting. That way, the compliance that the company has made in relation to social and environmental policies can be shown in financial statements.

This research suggests to the next researcher to find other data sources to test this issue, since testing using other data sources on the same object, not only corroborates the research findings but also to validate the data itself. The use of data that relies solely on a single company's database may be biased. By using from other sources, research results can be mutually supportive and the generalization capability will be stronger. 


\section{ACKNOWLEDGEMENT}

This research was funded using the scheme of Professor Grants in the Research and Community Service Institution, Universitas Lampung, 2018. For this reason, the authors would like to thank for this funding.

\section{ORCID}

Lindrianasari Lindrianasari (iD https://orcid.org/0000-0003-0219-9482

\section{REFERENCES}

Arvidsson, S. (2010). Communication of Corporate Social Responsibility: A Study of the Views of Management Teams in Large Companies. Journal of Business Ethics, 96(3), 339-354. https://doi.org/10.1007/s10551-0100469-2

Asmaranti, Y., \& Lindrianasari, L. (2014). Comparation of Greenhouse Gas Emission Disclosure Before and After Enactment of the Indonesia Act No. 17 of 2004. Issues in Social and Environmental Accounting, 8(4), 225234.

Kamal, Y., \& Deegan, C. (2013). Corporate Social and Environment-related Governance Disclosure Practices in the Textile and Garment Industry: Evidence from a Developing Country. Australian Accounting Review, 23(2), 117-134. https://doi.org/10.1111/j.1835-2561.2012.00205.x

Lindrianasari, L., Kufepaksi, M., Asmaranti, Y., \& Komalasari, A. (2018). Social and Environmental Responsibility in Developing Countries: A Theoretical Approach to Regulation. International Journal of GEOMATE, 15(49), 47-52. https://doi.org/10.21660/2018.49.3684

Scott, W. R. (2015). Financial Accounting Theory (7th ed.). Toronto: Pearson.

Seo, S. N. (2017). Beyond the Paris Agreement: Climate Change Policy Negotiations and Future Directions. Regional Science Policy and Practice, 9(2), 121-140. https://doi.org/10.1111/rsp3.12090

Sharfman, M. P., \& Fernando, C. S. (2008). Environmental Risk Management and the Cost of Capital. Strategic Management Journal, 29(6), 569-592. https://doi.org/10.1002/smj.678

Suchman, M. C. (1995). Managing Legitimacy: Strategic and Institutional Approaches. The Academy of Management Review, 20(3), 571-610. https://doi.org/10.2307/258788

Zunino, L., Tabak, B. M., Figliola, A., Pérez, D. G., Garavaglia, M., \& Rosso, O. A. (2008). A Multifractal Approach for Stock Market Inefficiency. Physica A: Statistical Mechanics and Its Applications, 387(26), 6558-6566. https://doi.org/10.1016/j.physa.2008.08.028 